\title{
THE EFFECT OF SERVICE QUALITY ON SATISFACTION AND ITS IMPACT ON LOYALTY OF COOPERATIVE MEMBERS
}

\author{
Arizal N., Associate Professor \\ Seswandi Agus, Lecturer \\ Faculty of Economics, University of Lancang Kuning, Indonesia \\ *E-mail: arizal@unilak.ac.id
}

\begin{abstract}
The objective of this study is to know empirically the effect of service quality on satisfaction and its impact on the loyalty of the members of savings and credit cooperative. In this study, the research method uses a descriptive method (Survey) with the quantitative research design, data that users are primer and secondary sources of data. A research population includes all members of savings and credit cooperative in Kasikan Kampar regency. In this study, the sample size consists of 95 respondents, which sample size determination based on Slovin's formula with the $10 \%$ margin of error. The sampling technique uses non-random sampling, particularly the method of accidental sampling with the help of SPSS assistance. The results of the research, these three dimensions have a significant influence on satisfaction. there is a positive relationship with the satisfaction and the results of research for empathy dimension indicate that there is a positive relationship with a satisfaction, but both dimensions do not have a significant effect on satisfaction, there is a positive relationship to loyalty and has a significant influence.
\end{abstract}

\section{KEY WORDS}

Service quality, satisfaction, loyalty, public service.

The cooperative is a business entity consisting of the person or cooperative legal entity that lies its activity based on the principle of cooperation and also as a people's economic movement based on the principle of kinship (based on the provision of Law No. 25 of 1992 concerning Cooperatives). Furthermore, the Cooperative aims to advance the welfare of members in particular and the community in general and participate in building the national economic order in order to create an advanced, justice and prosperous society based on Pancasila and the 1945 Constitution. The form of business entity should have a large role in the development and welfare of the Indonesian people.

In Indonesia, the role of cooperatives in contributing to national income is not yet high; this can be seen from the contribution of presentations from 2014 to 2017 . Which is 2017 the contribution of cooperatives in Indonesia was 1,715, in 2015 it developed to 4.41\%. In 2016, the role of Indonesian Cooperatives on national income decreased to 3.4\%, while in 2017 it increased again by around $4.6 \%$. Based on these data, the role of cooperatives in Indonesia to national income fluctuated from 2014 to 2017 and from these figures, it can be seen that their role is quite small.

One of the goals of establishing a cooperative is to be able to improve the welfare of its members. The purpose of the cooperative in its activities can choose various fields, namely the production sector, the field of service provision, the field of goods supply and lending to its members.

In running its business, cooperatives can appoint a manager who has the task to carry out cooperative activities and try to achieve cooperative goals and can make cooperatives that are developed and large-scale. Therefore, cooperative products must be able to provide a good level of service quality, which has 5 dimensions according to Kotler in Alma (2005: 284-285) and also Davis in Tjiptono (2016) and according to Parasuraman in Sopiah (2013) namely; Tangible (tangible); Reliability (reliability), Responsiveness (fast response); Assurance (certainty) and Empathy (empathy). 
Good service quality is the expectation of the customer, in this case, is a member of the cooperative, because this will be able to bring satisfaction. Customer satisfaction has become a central concept in business and management discourse (Tjiptono and Chandra, 2005: 192). Customers generally expect the product in the form of goods or services consumed can be accepted and enjoyed with good or satisfying service (Assauri, 2003: 8).

Satisfying service can bring loyalty, and this is the hope of all companies both engaged in goods and services. The importance of loyal customers according to Griffin (2003; 223) include: Reducing marketing costs (because low costs can attract new customers); Reducing transaction costs (such as contract negotiation fees, order processing); Reducing customer turnover costs (due to fewer customer changes); Increase cross-sales which will enlarge the company's market share; A more positive of word of mouth assuming that loyal customers also means those who are satisfied.

Foster $(2008 ; 175)$ proposed several indicators of loyalty, namely: doing regular purchases; Buy between lines of products and services; Recommend products to other people (refers other); Demonstrate competitiveness with other competitors.

\section{LITERATURE REVIEW}

The good quality of service provided by companies to customers or members of cooperatives can bring satisfaction. Satisfaction felt by customers or members of the cooperative will be able to bring loyalty from customers, which mean that the level of loyalty is determined by the level of satisfaction and the level of satisfaction obtained by customers, one of which is determined by the quality of service.

Tjiptono, et al (2008: 70) service quality reflects the comparison between the level of service provided by the company compared to customer expectations. This means that customer expectations should be the same as the services provided by the company.

The study of SERVQUAL by parasuraman (1988) in Lupiyoadi; 2006; 182 concluded that there are five dimensions of service quality called SERVQUAL. Those are:

1. Tangibles (Tangibles), is the ability of a company to provide physical evidence to customers, both in terms of humans, the shape of buildings and equipment used in the service process;

2. Reliability (Reliability) is the ability of the company to provide services in accordance with what was promised accurately and reliably;

3. Responsiveness (Responsiveness), which is the ability of a company to help and provide fast and appropriate services to customers and clear information;

4. Assurance (Assurance) (i.e. in the form of knowledge, politeness, and the ability of the company employees to foster the trust of customers to the company. Its components include communication (communication), credibility (credibility), security (security), competence (competence) and courtesy (courtesy);

5. Empathy (Empathy). Give sincere, individual or personal attention given to customers by trying to understand consumer desires.

According to Kotler, satisfaction is the level of one's feelings after comparing the performance or results he feels compared to his expectations (Kotler et al, 2000: 52). Whereas Tse and Wilton (1988) in Lupiyoadi (2004: 349) customer satisfaction or dissatisfaction is the customer's response to the evaluation of the disconfirmation between the previous expectations and the actual performance of the product felt after its use. Wilkie (1990) defines satisfaction as an emotional response to an evaluation of the consumption experience of a product or service. Engel, et al (1990) states that customer satisfaction is an evaluation after the transaction process where the alternative is chosen is at least the same or exceeds customer expectations, while dissatisfaction arises if the results (outcomes) do not meet expectations (Tjiptono, 2004: 349). Customer satisfaction is the response of the customer to the discrepancy between the level of interest before and the actual performance felt after use (Rangkuti, 2002: 30). Customer satisfaction is influenced by perceptions of service quality, product quality, prices and factors that are personal as well as those of a momentary situation (Kotler, 2000: 41). 
Customer satisfaction has become a central concept in business and management discourse (Tjiptono and Chandra, 2005: 192). Customers generally expect products in the form of goods or services consumed that can be received and enjoyed with good or satisfying service (Assauri, 2003: 8). Customer satisfaction can shape perceptions and then can position the company's products based on customers. If performance is below expectations, the customer is not satisfied, if performance meets satisfying customer expectations. If performance exceeds expectations, the customer is very satisfied or happy.

Loyal service will bring benefits, Griffin (2003; 223), namely;

- Marketing costs will be reduced (because the cost to attract new customers is more expensive);

- Will reduce transaction costs (such as contract negotiation fees, order processing, etc.);

- Customer turnover costs will be reduced (due to fewer customer changes);

- Increase cross-sales which will enlarge the company's market share;

- Word of mouth (a promise from mouth to mouth) is more positive assuming that loyal customers also mean those who are satisfied.

Furthermore, Griffin stated the characteristics of loyal customers, namely;

- Routinely use certain types of services from a company;

- Use other services from the company;

- Willingness to recommend company services to other parties/people;

- Courage to reject the company's competitors' offers.

From the research results of Tuti Hastuti et al 2014, with the title Service Quality, Customer Satisfaction, and Customer Loyalty: SERVQUAL Model Application in Malang Islamic Microfinance Institutions. In this study, the sample used was 112 respondents as customers of Sharia Microfinance Institutions (LKMS) Malang. Research results: Service quality has a significant effect on customer satisfaction, while tangibles and empathy dimensions have no effect on satisfaction. In addition, another result is that service quality has a significant effect on customer loyalty through customer satisfaction.

Furthermore, the study entitled The Effect of Service Quality on Customer Satisfaction and Loyalty of PT BPR HOKI in Tabanan Regency by Dewi et al. (2014: 257). The results of statistical analysis show that service quality, customer satisfaction, and loyalty have a positive and significant relationship

Research by Dewi et al. (2014: 257), states that service quality, customer satisfaction, and loyalty have a positive and significant relationship. Likewise, research by (Rizan, 2011) with the title Effect of Product Quality and Service Quality on Customer Satisfaction states product quality and service quality have a significant effect on Suzuki customers. Furthermore, research from (Rachmawati \& Azis, 2017) states that consumer satisfaction with the quality of hotel services. Service quality also has a significant effect based on research conducted by (Ersi \& Semuel, 2014), (Trisno Musanto, 2004), (Wahyudi, 2015).

\section{METHODS OF RESEARCH}

This type of research is a descriptive method (survey) with a qualitative research design, which is to determine the implementation, the quality of service and satisfaction and loyalty. In addition, quantitative design, namely research not only provides a description of the phenomenon but also explains, tests the hypothesis and gets the meaning of the facts.

Types and sources of research data in the form of primary data and secondary data. The population in this study were all members of Maju Bersama savings and credit cooperatives in Kasikan Kampar regency in 2017, totaling 1,492 people. Because of the large population, then in this study took a sample of 5 respondents using Slovin theory with an error rate of $10 \%$.

Types of Sampling Techniques. The method used in this research is non-random sampling technique by accidental sampling method where each population found is used as a sample. 
In this research, the data analysis technique used is the questionnaire analysis method. Each questionnaire was taken from each research indicator and each answer was scored with very good criteria (5), to very poor (1). Analysis of the influence of the variables in this study using analysis tools with SPSS.

\section{RESULTS OF STUDY}

The characteristics used in this study consisted of; gender, age, education, occupation and duration of membership of the cooperative. The following are the results of respondents' characteristic research on Maju Bersama savings and credit cooperatives in the Kasikan Regency.

Table 1 - Characteristics of Respondents by Gender

\begin{tabular}{|c|c|c|}
\hline Gender & $\begin{array}{c}\text { Frequency } \\
\text { (Respondents) }\end{array}$ & $\begin{array}{c}\text { Percentage } \\
(\%)\end{array}$ \\
\hline Male & 36 & 37,90 \\
\hline Female & 59 & 61,10 \\
\hline Total & 95 & 100 \\
\hline
\end{tabular}

Source: Data Processed.

Based on the table above, it can be seen that the majority of respondents are women, namely 59 people or $61.10 \%$, while men are 36 or $37.90 \%$. This means that the members of the cooperative are dominated by women.

The following are the characteristics of respondents based on their level of education can be seen in the table below.

Table 2 - Characteristics of Respondents by Education Level

\begin{tabular}{|c|c|c|}
\hline Education & $\begin{array}{c}\text { Frequency } \\
\text { (Respondents) }\end{array}$ & $\begin{array}{c}\text { Percentage } \\
(\%)\end{array}$ \\
\hline Junior High School & 26 & 27,40 \\
\hline Senior High School & 44 & 46,30 \\
\hline Associate Degree & 12 & 12,60 \\
\hline Bachelor's degree & 13 & 13,70 \\
\hline Amount & 95 & 100,0 \\
\hline
\end{tabular}

Source: Data Processed.

Based on the above table, it can be seen that the majority of respondents are respondents who are educated at the Senior High School level as many as 44 people or $27.40 \%$ while those with Junior High School are 26 people or $27.40 \%$, who have a diploma education of 12 people or $12.60 \%$ and those with an undergraduate education of 13 people or $13.70 \%$.

Table 3 - Characteristics of Respondents Based on Employment

\begin{tabular}{|c|c|c|}
\hline Employment & $\begin{array}{c}\text { Frequency } \\
\text { (orang) }\end{array}$ & $\begin{array}{c}\text { Percentage } \\
(\%)\end{array}$ \\
\hline Students & 7 & 7,40 \\
\hline Civil Servants & 12 & 12,60 \\
\hline Entrepreneur & 32 & 33,70 \\
\hline Others & 44 & 46,30 \\
\hline Total & 95 & 100,0 \\
\hline
\end{tabular}

Source: Data Processed.

From the above table, it can be seen that there are 7 people or $7.40 \%$ of cooperative members who have worked as students or students, there are 12 people as civil servants or $12.60 \%$ and there are 32 people as entrepreneurs. While the remaining 44 people or $46.30 \%$ 
are having other jobs. To find out whether each question item is valid, a validity test is carried out where the results can be seen in the following table:

\begin{tabular}{|c|c|c|c|c|c|}
\hline \multicolumn{6}{|c|}{ Table 4 - Uji Validity } \\
\hline Varible & Dimension & INDICATOR & $\begin{array}{c}\text { Corrected Item } \\
\text { Correlation }\end{array}$ & $\begin{array}{l}r \text { table } \\
\text { (Significan? } \\
\text { Level } 5 \% \text { ) }\end{array}$ & Information \\
\hline \multirow{19}{*}{$\begin{array}{l}\text { Service } \\
\text { Quality }\end{array}$} & \multirow{5}{*}{ Tangible } & BF1 & 0.551861 & 0,3202 & Valid \\
\hline & & BF2 & 0.736741 & 0,3202 & Valid \\
\hline & & BF3 & 0.561642 & 0,3202 & Valid \\
\hline & & BF4 & 0.566935 & 0,3202 & Valid \\
\hline & & BFS & 0.757664 & 0,3202 & Valid \\
\hline & \multirow{4}{*}{ Reliability } & KH1 & 0.759624 & 0,3202 & Valid \\
\hline & & $\mathrm{KH} 2$ & 0.779216 & 0,3202 & Valid \\
\hline & & $\mathrm{KH} 3$ & 0.811477 & 0,3202 & Valid \\
\hline & & $\mathrm{KH} 4$ & 0.833199 & 0,3202 & Valid \\
\hline & \multirow{4}{*}{$\begin{array}{l}\text { Responsivin } \\
\text { ess }\end{array}$} & DT1 & 0.793322 & 0,3202 & Valid \\
\hline & & DT2 & 0.762588 & 0,3202 & Valid \\
\hline & & DT3 & 0.794428 & 0,3202 & Valid \\
\hline & & DT4 & 0.859385 & 0,3202 & Valid \\
\hline & \multirow{3}{*}{ Asurance } & JM1 & 0.919353 & 0,3202 & Valid \\
\hline & & JM2 & 0.848800 & 0,3202 & Valid \\
\hline & & JM3 & 0.859858 & 0,3202 & Valid \\
\hline & \multirow{4}{*}{ Empaty } & EP1 & 0.668158 & 0,3202 & Valid \\
\hline & & EP2 & 0.770696 & 0,3202 & Valid \\
\hline & & EP3 & 0.795544 & 0,3202 & Valid \\
\hline \multirow{9}{*}{ Satisfaction } & & EP4 & 0.740663 & 0,3202 & Valid \\
\hline & & AP1 & 0.844539 & 0,3202 & Valid \\
\hline & & AP2 & 0.889715 & 0,3202 & Valid \\
\hline & & AP3 & 0.643075 & 0,3202 & Valid \\
\hline & & AS1 & 0.795050 & 0,3202 & Valid \\
\hline & & AS2 & 0.845912 & 0,3202 & Valid \\
\hline & & AS3 & 0.792740 & 0,3202 & Valid \\
\hline & & $\mathrm{AB1}$ & 0.845642 & 0,3202 & Valid \\
\hline & & $A B 2$ & 0.779457 & 0,3202 & Valid \\
\hline \multirow{5}{*}{ Loyalty } & & AB3 & 0.743870 & 0,3202 & Valid \\
\hline & & L1 & 0.869507 & 0,3202 & Valid \\
\hline & & L2 & 0.898954 & 0,3202 & Valid \\
\hline & & L3 & 0.427918 & 0,3202 & Valid \\
\hline & & L4 & 0.859003 & 0,3202 & Valid \\
\hline
\end{tabular}

Source: Data Processed.

From the table above, it can be viewed that all question items from each research variable are valid. Meanwhile, to find out whether a reliable instrument to be used as a data collection tool is used the reliability test. The reliability coefficient is good if $>0.60$.

From the table above, it can be seen that the results of reliability testing indicate that the reliability coefficient value is greater than the stipulation of 0.60 , then the test results indicate that all instruments are reliable.

Table 5 - Reliability Test Results

\begin{tabular}{|c|c|c|c|}
\hline Variabel & Cronbach's Alpha & Value & Status \\
\hline Tangible & 0,634513 & 0,60 & Reliable \\
\hline Reliability & 0,807193 & 0,60 & Reliable \\
\hline Responsiviness & 0,81168 & 0,60 & Reliable \\
\hline Assurance & 0,841495 & 0,60 & Reliable \\
\hline Empaty & 0,730523 & 0,60 & Reliable \\
\hline Satisfaction & 0,716264 & 0,60 & Reliable \\
\hline Loyalty & 0,726291 & 0,60 & Reliable \\
\hline
\end{tabular}


Table 6 - One-Sample Kolmogorov-Smirnov Test

\begin{tabular}{|c|c|c|}
\hline & & Unstandardized Residual \\
\hline$N$ & & 49 \\
\hline \multirow[t]{2}{*}{ Normal Parameters ${ }^{a}$} & Mean & .0000000 \\
\hline & Std. Deviation & 2.86559103 \\
\hline \multirow[t]{3}{*}{ Most Extreme Differences } & Absolute & .089 \\
\hline & Positive & .089 \\
\hline & Negative & -.080 \\
\hline Kolmogorov-Smirnov Z & & .622 \\
\hline Asymp. Sig. (2-tailed) & & .834 \\
\hline
\end{tabular}

a. Test distribution is Normal.

To test the normality of tangible variables, reliability, responsiveness, insurance and empathy for satisfaction. this can be seen from the table above. Wherefrom the KolmogorovSmirnov test one-sample table it is known that the significance value is 0.834 and greater than 0.05 . Then it can be concluded that the data tested is a normal distribution.

Table 7 - One-Sample Kolmogorov-Smirnov Test

\begin{tabular}{|ll|l|}
\hline & & Standardized Residual \\
\hline Normal Parameters & & \\
& Mean & 49 \\
Most Extreme Differences & Std. Deviation & .0000000 \\
& Absolute & .94648472 \\
& Positive & .089 \\
Kolmogorov-Smirnov Z & Negative & .089 \\
Asymp. Sig. (2-tailed) & & -.080 \\
\hline
\end{tabular}

a. Test distribution is Normal.

From the above table, it can be seen that from the table of the Kolmogorov-Smirnov one-sample test it is known that the significance value is 0.834 and greater than 0.05 . Then it can be concluded that the data tested is a normal distribution.

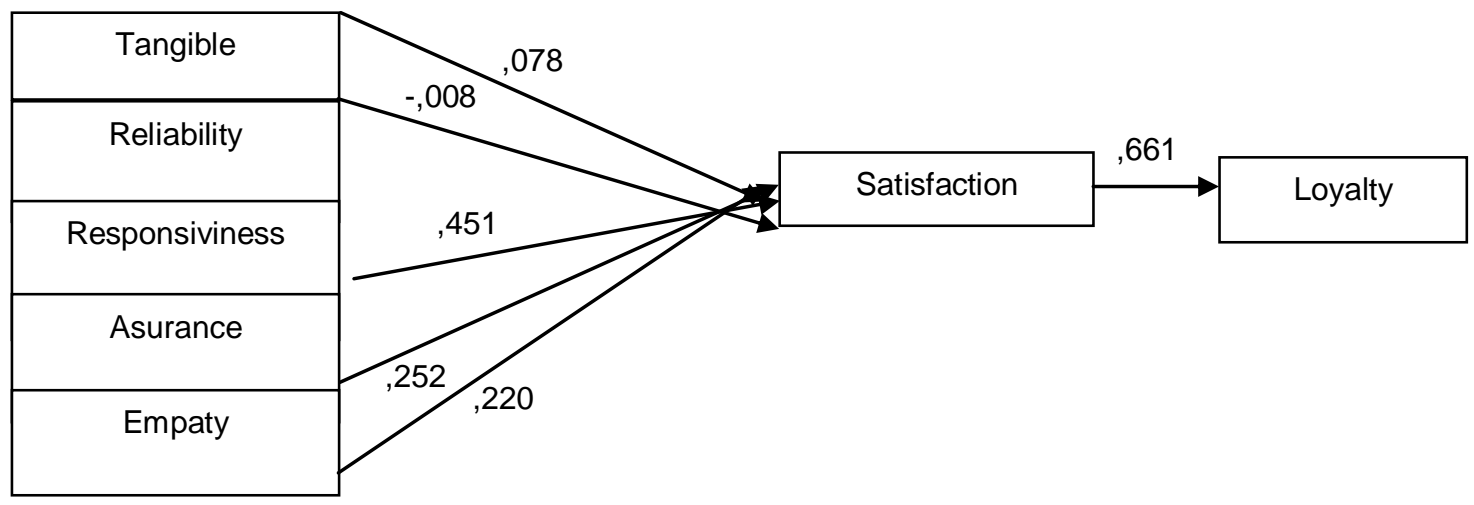

Figure 1 - Structural Research Model

The results of data processing using SPSS, the results obtained for the dimensions of physical evidence, that there is a positive relationship between physical evidence with a satisfaction level of 0.78 which means that if the provision of physical evidence is increased, then the level of satisfaction will positively increase as big as 0.78 . The test results for the significance level is 0.283 greater than 0.05 which means there is no significant effect. 
The results of the research on the reliability dimension show that there is a negative relationship between reliability and satisfaction level of -0.008 which means that if the provision of physical evidence is increased, the level of negative satisfaction is -0.008 . The test results for the significance level is 0.283 greater than 0.05 which means there is no significant effect.

The results of the research for the responsiveness dimension show that there is a positive relationship with the satisfaction level of 0.451 , which means that if the responsiveness of employees is increased, then the level of satisfaction will positively increase by 0.451 . From the test results for the significance level is 0,000 less than 0.05 which means there is a significant influence.

The results of the research for the assurance dimension show that there is a positive relationship with satisfaction of 0.252 , which means that if the assurance from the cooperative is improved, then the level of satisfaction will positively increase by 0.252 . From the test results for the significance level is 0.05 , which means there is a significant influence.

The results of research for the empathy dimension show that there is a positive relationship with a satisfaction level of 0.220 , which means that if empathy of employees is increased, then the level of satisfaction will positively increase by 0.220 . From the test results for the significance level is 0.004 smaller than 0.05 , which means there is a significant influence.

Based on the results of the study, it can be seen that from the five dimensions studied, three dimensions, namely responsiveness, assurance, and empathy have a partial effect on satisfaction. While the other two dimensions, namely tangible and reliability do not have a significant effect on satisfaction. But simultaneously that dimension of service quality has a significant effect on the satisfaction that is equal to 0.63 , which means that an improvement in the services provided by the company will increase consumer satisfaction by 0.63 . The results of the test of significance obtained a probability level of 0,000 and smaller than 0.05 .

On the satisfaction variable, the results of the study of the effect of satisfaction on loyalty from shows that there is a positive relationship of 0.661 , which means that a change in satisfaction provided by the company will increase customer loyalty by 0.661 . From the results of the test of significance obtained the probability level of 0.000 and less than 0.05 , which means there is a significant influence.

\section{RESULTS AND DISCUSSION}

The results of research for service quality variables of the five dimensions studied, then there are three dimensions, namely the dimensions of responsiveness, assurance, and empathy partially have a significant effect on satisfaction. While the other two dimensions, namely tangible and reliability do not have a significant effect on satisfaction. However, the dimensions of service quality have a significant simultaneous effect on the satisfaction that is equal to 0.63. This is in line with research Hastuti et al (2014), which states that the variable service quality has a significant effect on customer satisfaction, research Dewi et al (2014) shows that the results of statistical analysis show that service quality, customer satisfaction, and loyalty have a positive and significant relationship. Misbach, et al. (2013;), the results of the study stated that the service quality of Islamic banks has a significant effect on customer satisfaction and on trust.

The results of this study indicate that the dimension of satisfaction has a positive and significant effect on the loyalty of 0.661 . This is in line with the research of Mohsan et al. (2011), showing that customer satisfaction is correlated or has a positive relationship with loyalty. Khan and Fasih (2014), the results of research that service quality, customer satisfaction, and loyalty have a positive and significant relationship.

\section{CONCLUSION}

The results of the research for the responsiveness dimension show that there is a positive relationship with the level of satisfaction with the assurance dimension. The results 
showed that there was a positive relationship with the satisfaction and the results of the study for the empathy dimension showed that there was a positive relationship with the satisfaction. These three dimensions have a significant influence on satisfaction.

Whereas for physical evidence, there is a positive relationship with the satisfaction and the results of research for empathy dimension indicate that there is a positive relationship with a satisfaction, but both dimensions do not have a significant effect on satisfaction.

For the satisfaction variable, there is a positive relationship to loyalty and has a significant influence, which means that a change in satisfaction provided by the company will increase customer loyalty by 0.00 and less than 0.05 , which means there is a significant effect.

\section{RECOMMENDATIONS}

For the dimensions of responsiveness, assurance, and empathy, the hotel should improve the quality of services provided so as to increase the level of customer satisfaction. Besides that, with increased satisfaction from hotel customers will be able to increase customer loyalty.

\section{REFERENCES}

1. Alma, Bukhari., 2005, Manajemen Pemasaran and Jasa, CV Alfa beta, Bandung.

2. Dewi dkk, 2014, Pengaruh Kualitas Pelayanan Terhadap Kepuasan and Loyalitas Nasabah PT BPR HOKI di Kabupaten Tabanan.

3. Ayu, G., Ratih, P., Dewi, K., Nyoman, N., Yasa, K., \& Sukaatmadja, P. G. (2014).

4. Pengaruh kualitas pelayanan terhadap kepuasan and loyalitas nasabah pt bpr hoki di kabupaten tabanan, 5, 257-275.

5. Ersi, D. Y., \& Semuel, H. (2014). Analisis CRM, Kepuasan Pelanggan and Loyalitas Produk. Jurnal Manajemen Pemasaran, 8(1),1-8.

6. Fasih, M. (2014). Impact of Service Quality on Customer Satisfaction and Customer Loyalty : Evidence from Banking, 8(2), 331-354.

7. Hasan, Ali 2014 marketing and kasus kasus pilihan, penerbit CAPS (Center for Academic Publishing Service), Jakarta

8. Hastuti, T., \& Muhammad, N. (2014). Kualitas Pelayanan, Kepuasan, and Loyalitas Nasabah: Aplikasi Servqual Model Pada Lembaga Keuangan Mikro Syariah Kota Malang. Jurnal Manajemen and Akuntansi, 3(3), 1-16.

9. Griffin, Jill, 2005; Costumer Loyalty menumbuhkan \& Mempertahankan Kesetiaan Pelanggan, Penerbit Erlangga Jakarta.

10. Kingdom, U., Hikmawati, N. K., \& Sumawihardja, S. (2015). Influence Of Marketing Relations And Marketing Mix On Custumer Trust On Mobile Service Operators In Indonesia, III(11), 409-422.

11. Kotler, Philip and Keller, Kavin Lane (Alih Bahasa: Benyamin Molan). 2009, Manajemen Pemasaran, PT Indeks, Jakarta.

12. Kotler, Philip, 2000, Manajemen Pemasaran, Jilid 1, Alih Bahasa Drs. Jaka Wasana, MSM,Penerbit: Erlangga, Jakarta.

13. Rangkuti, Freddy 2002. Measuring coustemer Satifaction.: Gaining Customer

14. Misbach, I., \& Hadiwidjojo, D. (2013). Islamic Bank Service Quality and Trust: Study on Islamic Bank in Makassar Indonesia, 8(5), 48-61. https://doi.org/10.5539/ijbm.v8n5p48

15. Mohsan, F., \& Nawaz, M. M. (2011). Impact of Customer Satisfaction on Customer Loyalty and Intentions to Switch : Evidence from Banking Sector of Pakistan, 2(16), 263270.

16. Normasari, S., Kumadji, S., \& Kusumawati, A. (2013). Pengaruh Kualitas Pelayanan Terhadap Kepuasan Pelanggan, Citra Perusahaan and Loyalitas Pelanggan. Jurnal Administrasi Bisnis (JAB), 6(2), 1-9.

17. Penang, B., \& Kheng, L. L. (2010). The Impact of Service Quality on Customer Loyalty : A Study of, 2(2), 57-66. 
18. Pereira, D., Gusti, N., Giantari, K., \& Sukaatmadja, I. P. G. (2016). Pengaruh Seervice Qualiti Terhadap Satisfaction and Costumer Loyality Koperasi Dadirah Di Dili Timor Leste Fakultas Ekonomi and Bisnis Universitas Udayana, Bali, Indonesia 3, 455-488.

19. Rambat Lupiyoadi. 2004. Manajemen Pemasaran Jasa: Teori and Praktek.Jakarta: PT. Salemba Empat.

20. Rizan, M., Warokka, A., \& Listyawati, D. (2014). Relationship Marketing and Customer Loyalty: Do Customer Satisfaction and Customer Trust Really Serve as Intervening Variables?, 2014. https://doi.org/10.5171/2014.724178

21. Roostika, R. (2011). The Effect of Perceived Service Quality and Trust on Loyalty: Customer's Perspectives on Mobile Internet Adoption, 2(4).

22. Soliman, H. S. (2011). Customer Relationship Management and Its Relationship to the Marketing Performance, 2(10), 474-488.

23. Santoso 2011 Analisis Pengaruh Bauran Pemasaran Jasa and Kualitas Pelayanan terhadap Kepuasan Nasabah serta Dampaknya pada Loyalitas Nasabah (Studi pada Nasabah PD Bank Perkreditan Rakyat Wilayah Cirebon)

24. Tjiptono, Fandi and Gregorius Candra, 2008. Service, Quality, and Satisfaction. Andi Offset: Yogyakarta.

25. Fasih, M. (2014). Impact of Service Quality on Customer Satisfaction and Customer Loyalty : Evidence from Banking, 8(2), 331-354. 